This item was submitted to Loughborough's Research Repository by the author.

Items in Figshare are protected by copyright, with all rights reserved, unless otherwise indicated.

\title{
Past and present green economy initiatives, and capacity building and financial mechanisms for the future development of the Barbados energy sector
}

\section{PLEASE CITE THE PUBLISHED VERSION}

http://www.direkt-project.eu/

\section{PUBLISHER}

DIREKT- Small Developing Island Renewable Energy Knowledge and Technology Transfer Network

\section{VERSION}

AM (Accepted Manuscript)

\section{PUBLISHER STATEMENT}

This work is made available according to the conditions of the Creative Commons Attribution-NonCommercialNoDerivatives 4.0 International (CC BY-NC-ND 4.0) licence. Full details of this licence are available at: https://creativecommons.org/licenses/by-nc-nd/4.0/

\section{LICENCE}

CC BY-NC-ND 4.0

\section{REPOSITORY RECORD}

Rogers, Thomas, and Ksenia Chmutina. 2019. "Past and Present Green Economy Initiatives, and Capacity Building and Financial Mechanisms for the Future Development of the Barbados Energy Sector". figshare. https://hdl.handle.net/2134/10255. 
This item was submitted to Loughborough's Institutional Repository (https://dspace.lboro.ac.uk/) by the author and is made available under the following Creative Commons Licence conditions.

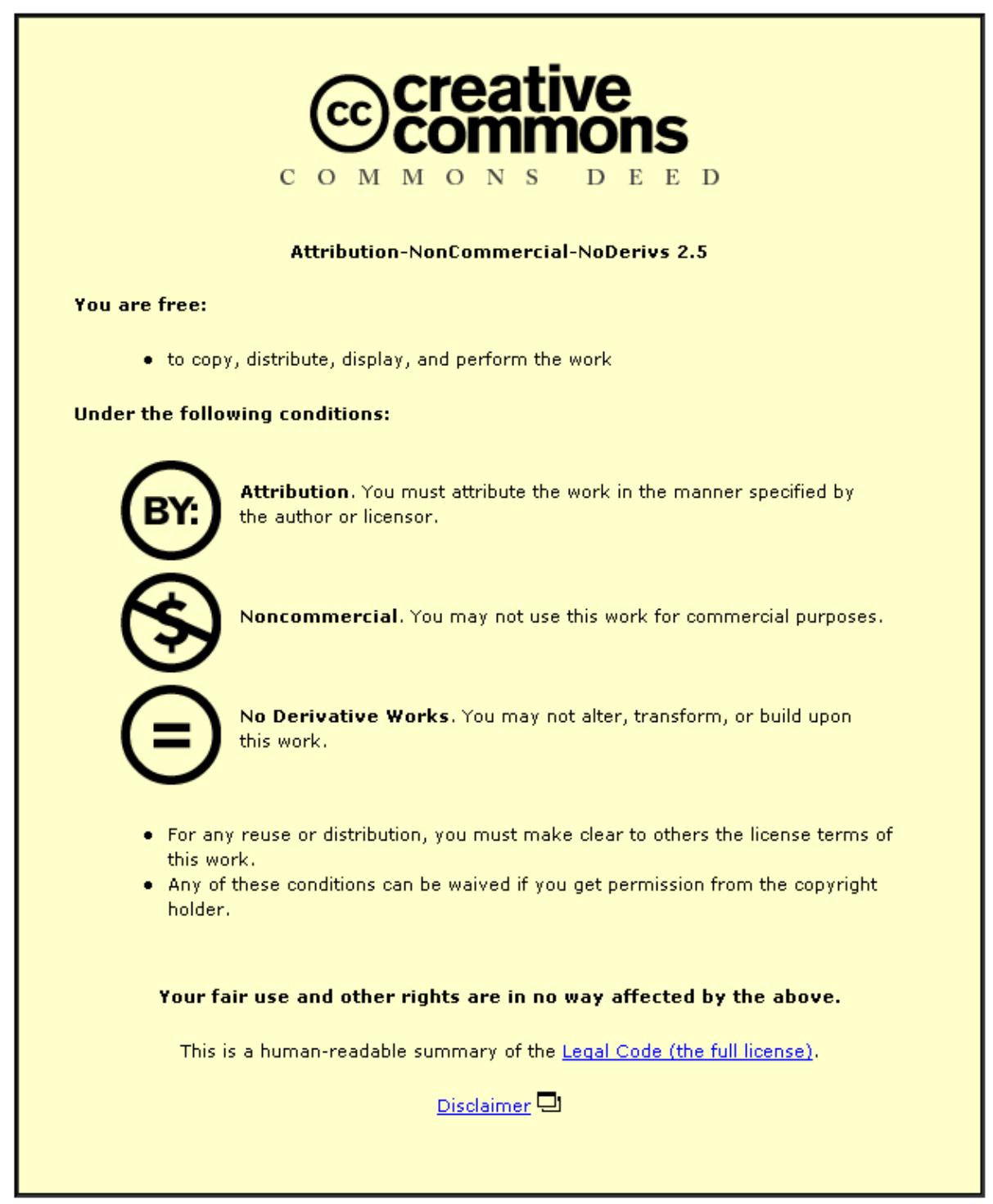

For the full text of this licence, please go to: http://creativecommons.org/licenses/by-nc-nd/2.5/ 


\title{
Past and Present Green Economy Initiatives, and Capacity Building and Financial Mechanisms for the Future Development of the Barbados Energy Sector
}

\author{
Tom Rogers $^{1 *}$ Ksenia Chmutina $^{2}$ \\ 1 - Department of Computer Science, Mathematics and Physics, The University of the West Indies, Cave Hill, Barbados \\ 2 - School of Civil and Building Engineering, Loughborough University, Loughborough, UK \\ * Corresponding Author. E-mail: thomas.rogers@cavehill.uwi.edu, Tel: +1246 4174158
}

\begin{abstract}
:
As with most Small Island Developing States (SIDS), imported fossil fuels make up the majority of Barbados’s primary energy requirements, including electricity generation. As well as using up valuable foreign exchange, this import bill makes the island highly vulnerable to the ever more volatile international energy market. Sustainable development has long been present in the islands ideological mind-set and in 2010 the Government of Barbados signalled its commitment towards becoming "the most environmentally advanced green country in Latin America and the Caribbean”. This paper first describes the island's present fossil fuel dominated energy sector, as well as past and present green economy related initiatives. It then discusses two key areas of energy sector reform necessary to promote sustainable development: capacity building and finance, highlighting the role that innovative financing mechanisms could play in decreasing the countries reliance on fossil fuel imports.
\end{abstract}

Keywords: Small Island Developing States, green economy, renewable energy, financing mechanisms

\section{INTRODUCTION}

Imported fossil fuels ( 9,000 barrels/day) cover most of Barbados’s primary energy requirements, including electricity generation. This import bill makes the island highly sensitive to the volatile international energy market (Fig. 1). In 2010 imported oil for electricity generation cost the country some US $\$ 300$ million (7.5\% of GDP). With few possibilities of expanding its own limited production of fossil fuels (the Barbados National Oil Company extracts $\sim 1000$ barrels/day), the most effective method of increasing energy security is to (1) contain demand growth by increasing energy efficiency, and (2) expand production from alternative energy sources [1]. Although much progress is now being made, neither of these two areas has an established policy/regulatory framework for the promotion of public or private investments [2].

The share of renewable energies in total primary energy supply has remained constant at slightly over 7 per cent over the last decade [3]. The source of renewable energy in the primary energy mix originates mainly from the use of solar water heaters and bagasse co-generation during the sugarcane-harvesting period (approximately 50-50 share between the two). The electricity generated from bagasse co-generation is all used in the sugar refining process/factories and there is currently no utility-scale renewable energy on the island. However, a 10MW wind farm has been held at the planning stage for over six years with installation now expected by 2014. There are also plans for a 13.5MW waste-to-energy plant, and a 17.5MW biomass co-generation plant.

The two largest consumers of the fuel imported onto the island by far are electricity generation (50 per cent) and transport (33 per cent). Of the total electrical energy generated in 2010 (1,036 GWh), domestic consumption was the major user at 31 per cent (see Fig. 2). The commercial sector was the second largest consumer with 22 per cent. Tourism, which includes hotels and numerous tourist attractions, was a close third with 17 per cent. In addition, a notable user of electricity is the water sector with most potable and irrigation water being either pumped from aquifers or via a 30,000 $\mathrm{m}^{3} /$ day reverse osmosis desalination plant. Barbados is classed as a water scarce island due to it 
being a relatively flat island with few rivers thanks to it consisting of predominantly permeable coral limestone.

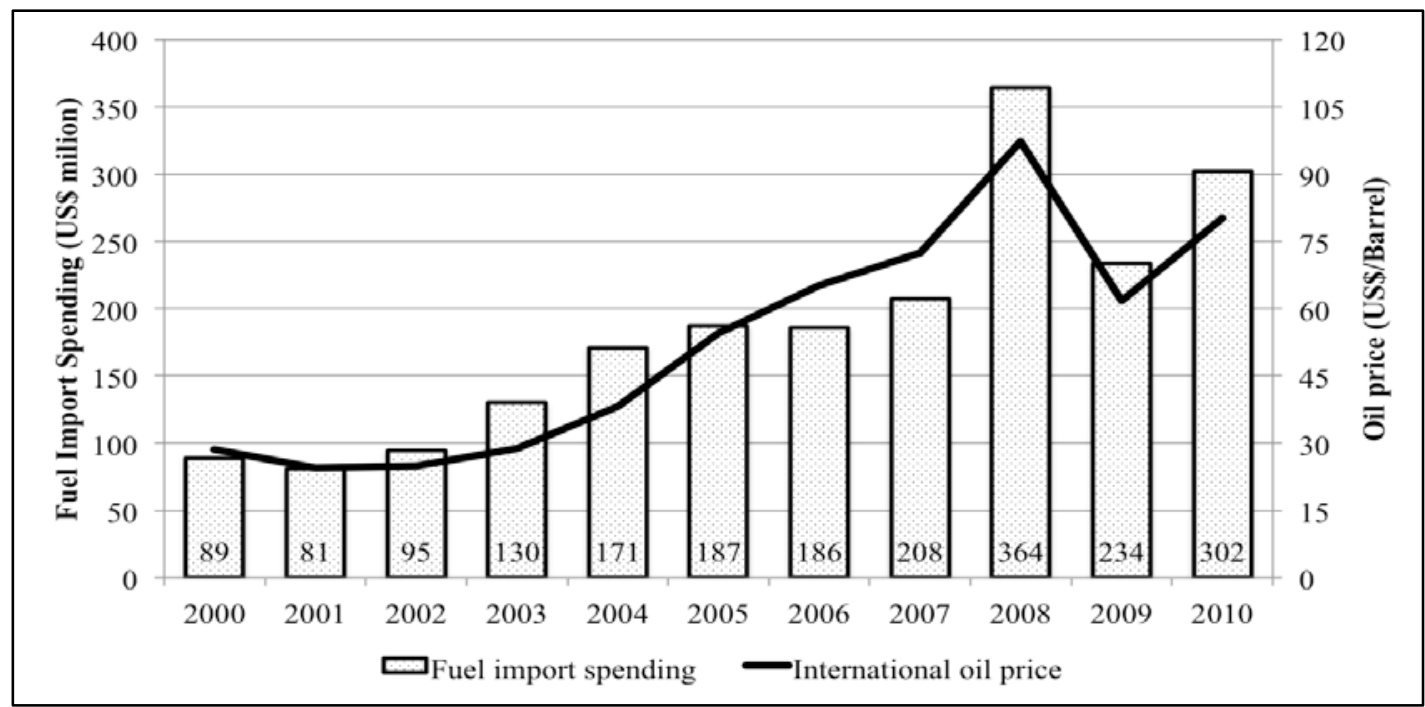

Fig. 1 Fuel import spending for electricity generation (Ministry of Finance and Economic Affairs)

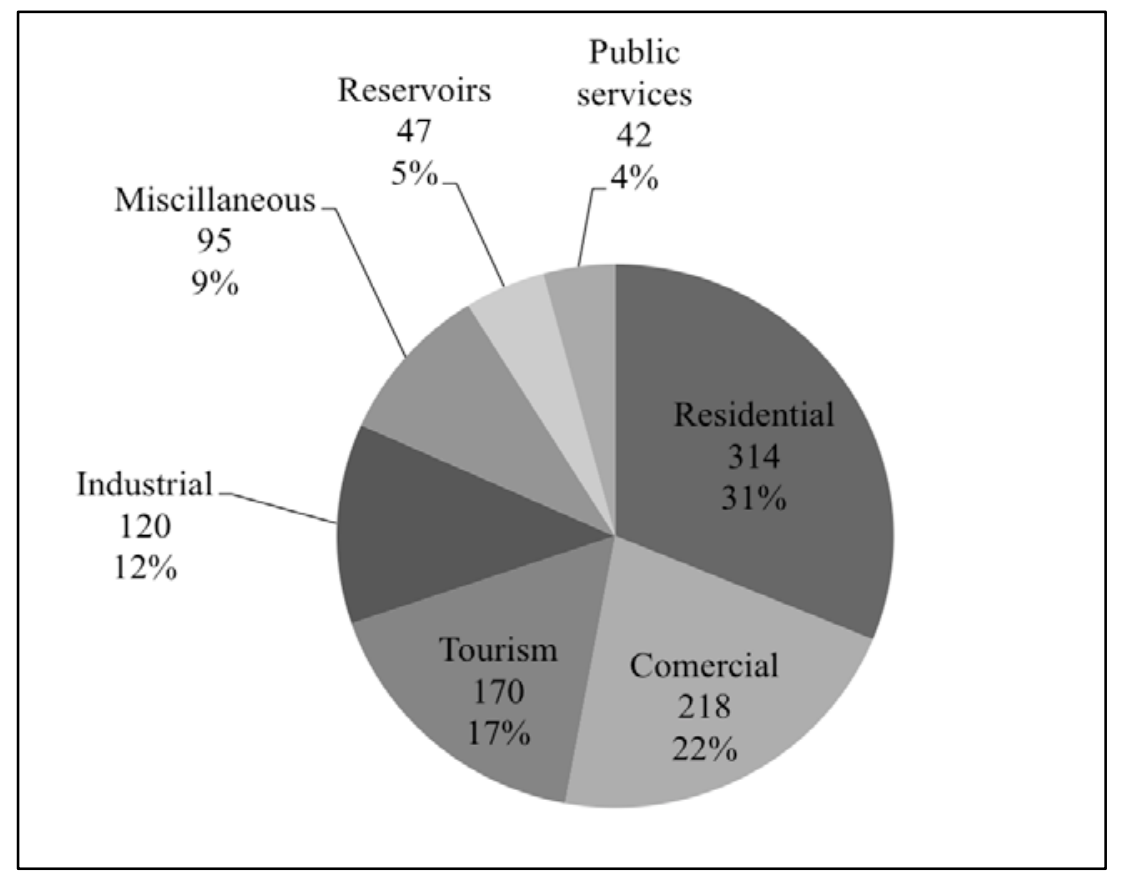

Fig. 2 Electricity consumption by sector for 2010 (GWh)

Fig. 3 shows that there has been a steady increase in electricity generation in recent years, with an average annual increase of $2.7 \%$ over the last 11 years. However, the electricity consumption per customer (commercial and residential) peaked in 2007 and has been slowly decreasing since. When the consumption is broken down between commercial and domestic customers (see Fig 4.), it is clear that the commercial customers are the main cause of this decrease. A steep increase in domestic electricity consumption was seen up until around 2005, since then consumption per customer has levelled. This levelling off coincides with the increase in energy prices, which occurred at the same time. The number of customers has increased by $19 \%$ since 1999 levels. 
Electricity generation on the island is produced by Barbados Light \& Power (BL\&P). Most of the generators they use for producing the islands electricity are diesel-electric units that run on heavy fuel oil. Some gas turbines are kept in reserve for peak loads and emergencies. Total installed capacity for the island is 240MW whilst the peak load for 2010 was 168MW.

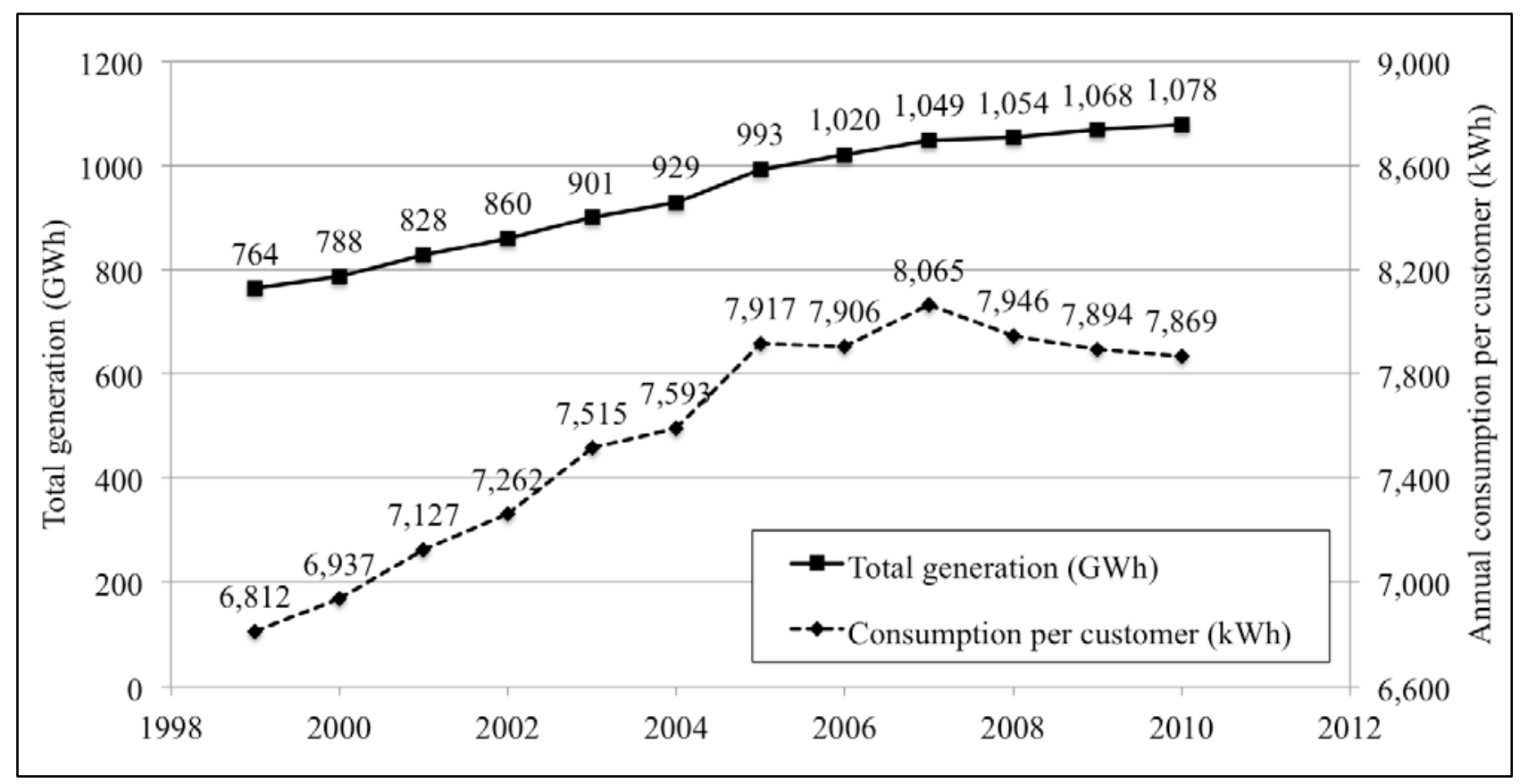

Fig. 3 Electricity generation and consumption per customer [4]
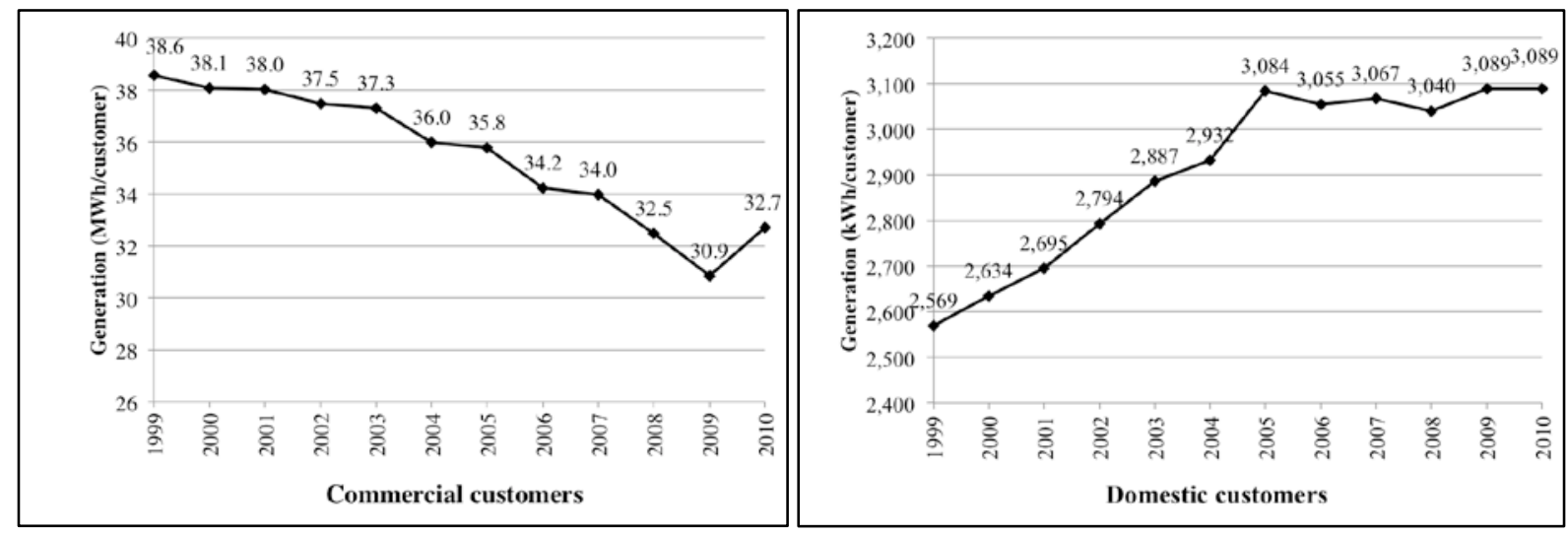

Fig. 4 Electricity consumption for commercial and domestic customers [4]

\section{GREEN ECONOMY}

The transition of Barbados towards a green economy was first proposed in the 2007 Statement of Economic and Financial Polices [5]. The Statement describes the green economy as:

"The practice of green economics recognises that because everything on earth is connected, synergies and linkages can be created within and between sectors often with resulting substantial increases in efficiency and productivity."

Past and present green economy initiatives for Barbados are described in the following sections.

\subsection{Past Green Economy initiatives}


With the exception of the widely acknowledged success of the Barbados solar hot water heating industry [6], which originated and grew from the 1970s global energy crisis, green economy related initiatives in Barbados are mainly confined to recent history. The National Sustainable Development Policy (NSD Policy) was published in 2004 with the aim of providing a clear outline as to what would be required in order to make the island more sustainable [7]. The policy is targeted at all persons, corporations and decision-makers. Its recommendations to the energy sector focus on conservation as well as the promotion of alternative renewable energy sources, in particular; support for Independent Power Producers (IPPs), the articulation of standards for energy efficient technologies, the encouragement of utility-scale use of renewable energy technologies, capacity building in education establishments (primary, secondary, tertiary and vocational establishments), and cooperation with the wider Caribbean region. Following this report various administrations adopted a number of green economy-related initiatives. The 2007 Statement of Economic and Financial Policies was the most broad-based to date outlining initiatives in the areas of energy, water, waste management, coastline protection and other policies to elicit behavioural change. For example, all businesses in Barbados can now write-off 150 per cent of the cost incurred to obtain international environmental certification. Since the 2007 budget, most of the public policy initiatives focused on energy, largely due to the impact that high oil prices have on the economies of small states. For example, all alternative energy systems are now exempted from import duty and households and businesses are allowed to write-off the costs of conducting energy audits and retrofitting their homes/buildings. A detailed list of some of the main historical green economyrelated initiatives can be found in the Green Economy Scoping Study (GESS) [1] and the Sustainable Energy Framework for Barbados (SEFB) [2].

\subsection{Present initiatives}

The Government of Barbados (GoB) has begun to introduce measures designed to increase the share of renewable energy supply and energy conservation measures, reflecting concerns about the GHG emissions and the terms-of-trade risks from fuel import costs. In an effort to utilise the island's favourable wind and solar resources, BL\&P together with the island's independent regulator, the Fair Trading Commission (FTC), introduced a 2-year trial known as the Renewable Energy Rider (which is effectively a Feed-in-Tariff) to lower the costs of renewable generation. The current payment is 1.8 times the fuel related element of the electricity tariff (currently US\$0.24 per $\mathrm{kWh}$ ) or US $\$ 0.158$ per $\mathrm{kWh}$, whichever is higher. This measure has no direct fiscal impacts since the costs are passed on to consumers by BL\&P (although there may be indirect effects for example on receipts from income and profit taxes). If this system were continued and expanded then the increase cost passed onto the consumer could eventually have repercussions on poorer sections of society; options would need to be explored to ensure that this does not occur.

To improve energy Demand Side Management (DSM), BL\&P are trialling a time-of-use tariff, whereby commercial customers can benefit from a lower electricity price during off-peak hours, and an Interruptible Service Rider for commercial customers who agree to have their supply interrupted thus reducing the reserve generating capacity required [4].

In addition, a Smart Energy Fund, financed through a loan from the Inter American Development Bank, has been established to promote renewable energy and energy conservation: of the US\$10 million total funding envelope, US\$6 million is set to be allocated to loans for energy auditing, energy conservation programmes and renewable energy technologies, while the remainder is to be used for grant finance, including for LED light bulbs and more efficient air conditioning units.

The 2011 Statement of Economic Policies continued to promote the use of energy conservation and alternative energy with initiatives aimed at helping homeowners, businesses, farmers and the 
vulnerable groups of society. The budget also included the submission of draft RE and EE policies, as well as draft legislation to facilitate the generation of RE systems and the sale of electricity to the grid.

\section{DISCUSSION}

Although the nation of Barbados has made progress in transitioning toward becoming a greener economy, there are still obstacles to its continued transition, in particular in the areas of financial and capacity enhancement. These obstacles are discussed in this section.

\subsection{Capacity enhancement}

As suggested in the 2007 Statement of Economic and Financial Polices [5] (see section 2), the importance of education, training, research, communication and sensitization to the green economy is paramount. The principals and benefits of a green economy need to be understood and practiced by all sectors of society in order to ensure its success.

To date, the sentiment often found in Barbados among businesses, farmers, householders and hotel owners is that there is a willingness to explore green economy initiatives (increasingly so as the cost of energy rises), however there is a significant 'skills gap' in meeting the needs for the green economy [1]. There is a need to put appropriate education and training arrangements in place. Training would need to focus on trade schools, universities, and on-the-job training in the workplace [8]. Solid R\&D, engineering, and manufacturing capacities are a critical aspect of building green industries and jobs. Indeed, some occupations in the renewables sector or in energy efficiency require highly educated and even quite specialized personnel, including a variety of technicians, engineers, and skilled trades. Green employment is not limited to high-end skills. There are many positions that demand a broad array of skills and experience levels, especially in installation, operations, and maintenance.

There is evidence that this process has already begun; with solar PV installation courses taught by experts, being arranged by BNOC and the GoB's Energy Division, renewable energy modules and programmes are now being offered at undergraduate and postgraduate level at the University of the West Indies, and the DIREKT [9] and INEES [10] projects at the UWI are encouraging renewable energy knowledge transfer between other SIDS and developed countries.

Elsewhere, evidence of private sector capacity building is evident, the Barbados Renewable Energy Association (BREA) was formed in the spring of 2011, and is a non-governmental association promoting the application of RE and EE technologies in Barbados. There are currently around twenty companies offering RE and EE solutions on Barbados. They serve both the public and private sector and their activities include; energy auditing; solar PV and solar thermal installation; small-scale wind installation; system design; biodiesel production; and consultancy. The association is committed to national development through ongoing lobbying for appropriate alternative energy policies and frameworks that benefit all energy users in Barbados and it will provide a collective voice to these RE and EE companies.

While access to RE and EE training has developed considerably in recent years, it is still a fundamental component of sustainable development and capacity-building for the long term, and would need to continue to expand, both in the current channels mentioned in the previous paragraph, and also in the area of public awareness and the workplace. As noted in the Barbados National Assessment Report 2010 [11], 
"communicating sustainable development to the general population is a challenge. For effective education, a variety of messages have to be transmitted to a number of different publics in differing formats. The resources required to adequately provide the volume of information required in the appropriate format have been ad hoc and information is usually provided in response to various situations. The approach to public education and information require streamlining and coordination and will be bolstered by the requisite information for decision-making".

There are still more areas that require urgent capacity enhancement. There is a requirement for increasing the amount of renewable energy positions in key areas, most notably the energy division's renewable energy unit. Given the importance that renewable energy and energy efficiency will have in energy policy for a green economy, the employment of additional renewable energy qualified staff is required. Another sector requiring capacity enhancement is the Government Electrical and Engineering Department (GEED), here currently the requirement is for training of existing employees in the certification of the installation of renewable energy technologies (namely solar PV and wind), rather than an increase in staff numbers [1].

\subsection{Options for financial incentives}

Although the costs of technical components have been declining, the investment in RE and some EE technologies are still expensive and to date, this has discouraged their deployment. High costs limit diffusion and create a negative reinforcing effect, which prevents the economies-of-scale that are needed to generate cost decreases. In addition, most of the RE technologies are new and not market-mature in Barbados, which creates high risks for investors, as their performance cannot be guaranteed. Nonetheless due to the high cost of electricity on the island some forms of renewable energy technologies are already economically viable. The SEFB highlights wind energy, waste-toenergy, solar water heating, hybrid PV/Thermal and biomass cogeneration as RE technologies that are already commercially viable, with several other technologies close to becoming viable if oil prices continue to rise [2].

Although many technologies are already viable, financial constraints (i.e. limited access to capital) are currently limiting the uptake of RE technologies, and this issue is being experienced across the private, public, and third sectors (i.e. voluntary, non-government and community sectors). Particular aspects of this barrier are the timescales of securing funding, the risks for investors, particularly with regard to the timescales involved, the difficulty of finding funding for feasibility and bidding stages of projects, and the lack of funding for paying person hours (revenue as opposed to capital). These constraints, particularly in the public sector, also include the issues of what they can borrow and whom they can lend to. Possible financing solutions to reduce this financial burden are the subject of the remainder of this discussion section and concentrate on innovative Hybrid PrivatePublic partnerships (PPP) and Energy Performance Contracting (EPC).

\subsubsection{Hybrid private-public partnerships}

Usually, governments have two ways of financing a solar programme; either with tax-exempt bonds (government-owned approach), or by entering into turnkey relationships with private solar developers. In the case of the local government-owned approach, government issues debt that typically has to be repaid over the useful life of the project. Also under this approach the government owns the system as well as retains all the benefits of the ownership other than the federal tax benefits; however, the debt adds to the burden of government and requires a procurement process to design, acquire and install the solar project. In this case the financing can be 
obtained at tax-exempt rates, and the government could receive revenue from selling the electricity to the power utility in order to lower the overall costs of the solar project $[12,13]$.

The turnkey solar developer-owned approach is typically used when the government lacks knowledge or experience in solar project development. In this case the government engages a private developer to build and own the project: the private developer gains access to the roof of the local government buildings through a license and access agreement. The private developer designs, finances, installs, operates, and maintains the solar system and then sells the renewable energy back to the local government through a Power Purchase Agreement (PPA) [11,12].

These two approaches can be incorporated together: by doing so, the PPP takes advantages of both options, while minimizing drawbacks [14]. The idea of the hybrid approach is that the government provides the financing through a bond issuance. Normally a third party - such as an Energy Agency or an Improvement Authority- is introduced in order to act as a facilitator between the government, the solar developer and the sites where the technology is to be installed. This third party issues bonds supported by the credit of the government and, therefore, significantly lowers the costs of capital for the projects. The project then uses a turnkey approach, with the difference that the financing being provided at the lower cost of capital is obtained by government. This allows a cheaper financing for the solar development community as well as preserves the developer's capacity to borrow from the private capital lending sources for other projects [12].

One example of this approach is the Morris Model implemented in New Jersey, USA [15]. The programme started in 2009 and the Local Financial Board approved the Morris County Improvement Authority (MCIA) bonds of up to \$30 mln [13]. The MCIA issued \$21.6 million of debt at a $4.46 \%$ net interest cost with a county guarantee to fund $3.2 \mathrm{MW}$ of solar projects. The MCIA has completed the first phase of its award winning renewable energy project, installing 13,629 solar panels at locations in 5 school districts and several county government facilities throughout the county. These installations provide the county with $3.1 \mathrm{MW}$ of clean energy and around $\$ 3.8 \mathrm{mln}$ in energy savings, and approximately 7,000 tonnes of carbon dioxide equivalent $\left(\mathrm{CO}_{2} \mathrm{e}\right)$ emissions.

\subsubsection{Energy Performance Contracting}

While PPPs are used for financing renewable energy technologies, EPC can be used for energy efficiency projects, such as building retrofits. EPC, or energy service performance contracting, is a mechanism to deliver energy efficiency products. It is a financing mechanism that includes energy savings guarantees and associated design and installation services provided by the Energy Service Companies (ESCOs) [16]. EPC can be broadly defined as a contract between ESCO and a client involving an energy efficiency investment in the client's facility, the performance of which is guaranteed by the ESCO, with financial consequences for the ESCO [17]. Under EPC, ESCO provides finance for a specific set of measures for energy efficiency retrofit, such as planning, building, operation \& maintenance, optimisation, fuel purchase, (co-) financing and user behavior motivation.

The contract between the ESCO and the building owner contains guarantees for cost savings and takes over financial and technical risks of the implementation and operation for the entire project duration (typically 5 to 15 years). The EPC service is paid by realised energy cost savings [18].

EPCs were originally introduced in the 1970s in North America due to the oil crisis. Currently ESCOs have successfully been implemented in many countries, such as Chile, China, the UK and almost all EU countries. One of the most well known programmes is the Berlin Energy Saving 
Partnership (BESP) [14], which is described in detail here. The State of Berlin first introduced the BESP in 1995. The concept is based on transferring energy management of state-owned properties to a partner, who uses private capital to self-finance the modernization of a building's infrastructure necessary to cut energy use and $\mathrm{CO}_{2} \mathrm{e}$ emissions. In return, the partner guarantees annual energy cost savings for the state [19].

Among refurbished buildings under the current BESP there are schools, nurseries, office buildings, leisure centres, theatres, universities and other municipal buildings. The general details of current contracts are presented in Table 1 . To date, implemented energy efficiency measures include refurbishment of heating and illumination, energy management as well as user motivation. User motivation is particularly important in this programme as building energy consumption often rises back once the projects are finished, therefore it is important to make building user aware of the energy consumption patterns and affect their energy use so the efficiency becomes habitual rather than behavioral.

Table 1. BESP results

\begin{tabular}{|l|l|}
\hline Number of contracts & 24 pools ( 1,400 buildings) \\
\hline Guaranteed savings (all contracts) & $\begin{array}{l}\text { US } \$ 14.9 \text { mln/year (including US\$3.6 mln/year savings in } \\
\text { Berlin public budget) }\end{array}$ \\
\hline $\mathrm{CO}_{2}$ reduction & $67,900 \mathrm{t} / \mathrm{a}$ \\
\hline Investment (all contracts) & $\mathrm{US} \$ 64.6 \mathrm{mln}$ \\
\hline
\end{tabular}

The process of the BESP is the following: Firstly, the Berlin Energy Agency confirms a building pool (the client). Buildings willing to take part in the programme have to fulfill the following criteria [20]:

- $\quad$ Secured ownership for at least 10 years;

- Steady use of the building and constant energy consumption in the past 3 years;

- Consumption of connected buildings (under-supply) is measurable;

- Modernisation and replacement of the central heating, ventilation and cooling devices are possible (no restrictions in supply contracts, devices owned by building owner);

- $\quad$ Minimum project size (baseline);

- If parts of the building are rented to third parties - allocation of the costs/savings has to be checked.

The client is responsible for the uptake of various buildings and is bound by contract to the utility company. In order to reduce its energy consumption, the client runs a competitive tendering process to transfer the financing, planning, implementation, and monitoring of energy saving measures to a private energy saving partner - the contractor. The main criteria for the contractor are specialist know-how (references), effectiveness and creditworthiness. The successful contractor undergoes a tendering process. While the contract between the client and the utility company is not affected by the project, the contractor, however, agrees on the necessary technology and supply with the energy supplier. When signing a contract with the client, the contractor guarantees a minimum level of energy savings - around $25 \%$. The contractor only receives his agreed earnings if the stated savings have been reached. At the same time, the client is able to save money through reducing heating and electricity consumption achieved through energy efficiency measures. The investment carried out by the contractor is also refinanced through these savings. Any remaining savings are shared by the partners according to a ratio system agreed in the contract. The contractor is responsible for 
maintenance and servicing of their system upgrades for the duration of the project (5 to 15 years), and the client fully profits from the full savings one the contract has expired [20]. This programme is not limited to large buildings with high-energy consumption: a group of smaller buildings can create 'a building pool' which allows less unprofitable buildings to be integrated in the project.

\section{CONCLUSIONS}

This paper has outlined the current status of Barbados's energy sector, highlighting the green economy related initiatives that are currently being explored. Building capacity in the RE and EE sector will continue to play a vital role in the islands transition towards a green economy. For a country such as Barbados, which has limited access to funding and is 'locked-in' to a fossil fuel based energy economy, financing mechanisms such as the hybrid Private-Public Partnerships and Energy Performance Contracting offer realistic opportunities for increasing its RE and EE capacity. Barbados has a number of energy use sectors that could significantly benefit from the financial initiatives described here. In particular Energy Performance Contracting is capable of providing substantial energy and emissions savings in its hotel and tourism sector, its government sector (including the Barbados Water Authority), the island's education establishments and its manufacturing sector.

\section{ACKNOWLEDGEMENTS}

The authors gratefully acknowledge the Green Economy Scoping Study team at The University of the West Indies Cave Hill campus, along with all those involved in the Green Economy Scoping Study.

\section{REFERENCES}

[1] Green Economy Scoping Study - Synthesis Report BARBADOS. (2012). United Nations Environment Program, The University of the West Indies, The Government of Barbados. Available at http://www.unep.org/greeneconomy/Portals/88/documents/SYNTHESIS\%20REPORT_Barba dos.pdf (accessed 2nd April 2012)

[2] Sustainable Energy Framework for Barbados - Final Report Volume 1. (2010). Government of Barbados, Inter-American Development Bank. Available at http://bajan.files.wordpress.com/2011/07/barbados-sustainable-energy-framework-vol-i.pdf (accessed 23rd February 2012)

[3] Schlegelmilch K. (2009). Options for promoting Environmental Fiscal Reform in EC Development cooperation - Country case studies of Barbados. Available at http://www.foes.de/pdf/2010-10_Environmental_Fiscal_Reform_EC_DC.pdf (accessed 23rd February 2012)

[4] BL\&P annual report. (2010). Light \& Power Holdings. Available at http://www.blpc.com.bb/photos/BLP\%20REPORT.pdf (accessed 23rd February 2012)

[5] Arthur, O. (2007). Minister of Finance. Statement of Economic and Financial Policies of the Government of Barbados. Available at:

http://www.barbadosparliament.com/htmlarea/uploaded/File/Budget/BUDGET\%20SPEECH \%202007.pdf (accessed 23rd February 2012)

[6] Headley, StC O. (1998). Solar Thermal Applications in the West Indies. Renewable Energy v15, pp 257-263

[7] Barbados Sustainable Development Policy. (2004). National Commission on Sustainable Development. Government of Barbados. Available at http://www.un.org/esa/dsd/dsd_aofw_ni/ni_pdfs/NationalReports/barbados/BarbadosSustaina bleDevelopmentPolicy.pdf (accessed 23rd February 2012) 
[8] DRAFT Transnational Recommendation Report - Barbados. (2012). The DIREKT project. The University of the West Indies. Manuscript in preparation. Will be available at http://www.direkt-project.eu/

[9] DIREKT - http://www.direkt-project.eu/ (Accessed $23^{\text {rd }}$ February 2012)

[10] INEES - http://www.uni-flensburg.de/projekte/inees (Accessed $23^{\text {rd }}$ February 2012)

[11] Barbados National Assessment Report. (2010). The Ministry of the Environment, Water Resources and Drainage. Government of Barbados. Available at http://www.sidsnet.org/msi_5/docs/nars/Caribbean/Barbados-MSI-NAR2010.pdf (accessed 23rd February 2012)

[12] Pearlman, S.B., and Scerbo, R.J. (2010). Local Renewables. In Public Utilities Fortnightly, March 2010.

[13] Pearlman, S.B., and Scerbo, R.J. (2010). Public-private partnership for renewable energy: a case study. In New Jersey Law Journal. March 1, 2010.

[14] Chegwidden, W.J., Pearlman, S.B. and Scerbo R.J. (2010). A county shares the light with local governments. In Energy. Date unknown.

[15] Chmutina, K. and Goodier, C. (2012). Potential of energy saving partnerships in the UK: an example of Berlin Energy Saving Partnership . Manuscript submitted for ICE Sustainability. Forthcoming.

[16] Xu, P.P., Chan, E.H.W. and Qian, Q.K. (2011). Success factors of energy performance contracting for sustainable building energy efficiency retrofit of hotel buildings in China. Energy Policy, 39, 7389-98.

[17] Taylor, R.P., Govindarajalu, C., Levin, J., Meyer, A.S. and Ward, W.A. (2007). Financing energy efficiency: lessons from Brazil. China, India, and Beyond. The World Bank. Available at http://www-

wds.worldbank.org/external/default/WDSContentServer/WDSP/IB/2008/02/18/000333037_2 0080218015226/Rendered/PDF/425290PUB0ISBN11OFFICIAL0USE0ONLY10.pdf (accessed 23rd March 2012).

[18] European Energy Service Initiative. (2009). The Idea of Energy Performance Contracting. Available at http://www.european-energy-service-initiative.net/eu/project/the-idea-of-energyperformance-contracting.html (Accessed 23rd March 2012).

[19] Siemens. (2011). Energy-Saving Partnership saves Berlin 5.3m euro annually. Available at http://www.thefuturebuild.com/desigo-reference-berlin-energy-987820/filefiles/033_Ref_Berlin_Energy_Saving_Partnership_110329.pdf (Accessed 23rd March 2012).

[20] Schlopsnies, U. (2009). Berlin's Energy Saving Partnership: a Model of Success. Presented in Helsinki, 14 November 2009. Available at http://www.dfhk.fi/fileadmin/ahk_finnland/Projekte/Veranstaltungen/Berlin_Vortrag_BEA_e nglisch.pdf (Accessed 23rd March 2012). 